Peer-Reviewed Article

ISSN: 2162-3104 Print/ ISSN: 2166-3750 Online Volume 7, Issue 2 (2017), pp. 367-394 (C) Journal of International Students http://jistudents.org/

\title{
Higher Education Institutions and International Students' Hindrances: A Case of Students From the African Portuguese-Speaking Countries at Two European Portuguese Universities
}

\author{
Susana Ambrósio \\ University of Aveiro, Portugal \\ João Filipe Marques \\ University of Algarve, Portugal \\ Lucília Santos \\ University of Aveiro, Portugal \\ Catarina Doutor \\ University of Algarve, Portugal
}

\begin{abstract}
We present a study to comprehend if the support given by higher education institution (HEI) to international students coming from the PortugueseSpeaking African Countries meets their academic and social hindrances. Our starting point was a set of semi-structured interviews focused on the perspectives of these students, their Professors and Course Directors as well as on the perspectives of HEI' staff. Despite findings indicate a positive institutional support, it seems there is still much to do in order to do it properly with these students. These different perspectives will allow us to reflect on the impact that those actions/resources have on the path of students from Portuguese-Speaking African Countries and to systematize suggestions to enhance their experiences in HE.
\end{abstract}

Keywords: International students' hindrances; Portuguese-Speaking African Countries; Higher Education Institutions; Institutional support. 
A research project on non-traditional students (NTS) has been carried out in two Portuguese Higher Education Institutions (HEI), University of Aveiro (UA) and University of Algarve (UAlg). The pertinence of this project, which started in May 2013, comes from the absence (to our knowledge) of systematized research on NTS in Higher Education (HE) in Portugal. The project is composed of four research lines, which relate to four different groups of NTS: (a) Mature students, (b) Students with disabilities, (c) Portuguese-Speaking African Countries' students and (d) Post-secondary technological specialization courses' students. The third line of research concerning students from the Portuguese-Speaking African Countries, which is the focus of the present article, will allow a detailed analysis on questions such as: who are these students, what are their hindrances, how do they deal with them and how do they experience their adjustment in HE in Portugal, particularly at the Universities of Aveiro and Algarve? Also, the research project will allow a better understanding of the university' role in the integration of students that come from African Countries, and to draw some suggestions at institutional level in order to make their transitions more successful.

According to the Portuguese Law and its terminology, students from Portuguese-Speaking African Countries are considered foreign students instead of international students (Decree-Law 36/2014, of March 10). In fact, these students are not 'estudantes internacionais' (international students) strictu sensu due the fact that they come to Portugal under special protocols for cooperation in the field of higher education (Decree-Law 393A / 99 of October 2) signed between Portugal and their countries of origin.

Nevertheless, since these students clearly fall within the definition of international students that is provided by the United Nations Educational, Scientific and Cultural Organization (UNESCO) and by the Organization for Economic Co-operation and Development (OECD), whether for scientific perspectives (Ferro, 2010; Mourato, 2011) and/or for an easier understanding and international comparison (Duque, 2012), we prefer to maintain the designation of 'international students'. Thus, according to the UNESCO Institute for Statistics (UIS) (2009) and OECD (2008), an international student is one who has left his or her country, or territory of origin, and moved to another country for the specific purpose of studying. Moreover, UIS and OECD, in collaboration with Statistical Office of the European Union (Eurostat), state that international students have to gather certain characteristics such as not have a permanent residence in the country where they pursue their studies and having obtained the entry qualification to their current level of study in another country (OECD, 2008; UNESCO Institute for Statistics, 2009).

The literature underlines that studying abroad implies many challenges and adjustments (Coates \& Dickinson, 2012). International 
students face unique challenges (Poyrazli \& Grahame, 2007) that are common all over the world and in different contexts and realities since they have to adjust to a new country and culture (Casa-Nova, 2005; Ferro, 2010; Sovic, 2008), a new education system (Casa-Nova, 2005) and, most of the time, to deal with a new language (Andrade, Evans, \& Hartshorn, 2014; Mourato, 2011; Semedo, 2010). Many students experience hindrances in their integration, either academically or socially (Rienties, Beausaert, Grohnert, Niemantsverdriet, \& Kommers, 2012), such as homesickness (Duque, 2012; Furnham \& Bochner, 1986; Pacheco, 1996) or discrimination and prejudice (Ferro, 2010; Poyrazli \& Lopez, 2007).

It seems to be generally accepted that international students have to have institutional support right from the beginning of their stay, since they are far away from their cultural, social and linguistic environment and have additional tendency to experience more difficulties than home students (Sovic, 2008). In this sense, HEI have the responsibility to provide the adequate support and enhance international students experience in the host institution (Akanwa, 2015).

The study presented in this article focuses on the experience of international students coming from Portuguese-Speaking African Countries, i.e., students from Angola, Cape Verde, Guinea-Bissau, Mozambique and Saint Tome and Principe, in two Portuguese HEI (UA and UAlg). Its central aim is to comprehend if the support given by the HEI to these students meets their hindrances at academic and social levels. To achieve this goal, we worked out an exploratory data collection of qualitative nature through semi-structured interviews. These interviews focused mainly on the perspectives of the students, their Professors and Course Directors as well as on the perspectives of the HEI' staff members. In more detail, we intend to: (a) describe the main hindrances experienced by these students at UA and UAlg; (b) identify the support structures and the actions promoted by both HEI in order to facilitate the Portuguese-Speaking African Countries' students adjustment in the host university; and (c) present some suggestions made by the students and their Professors concerning the institutional support. These different perspectives will allow us to reflect on the impact that those actions/resources have on the path of the students coming from the Portuguese-Speaking African Countries and to systematize suggestions to enhance their experiences in HE.

\section{LITERATURE REVIEW}

\section{International Students and Their Hindrances}

Among other skills, students develop in HE their ability to think reflectively and critically, to develop their value structures and moral sensibilities, their self-identity and their sense of career identity and 
vocational competence (Pascarella \& Terenzini, 2005). On the other hand, students are expected to make new friends, to have new social networks with new rules of sociability, to have new hobbies and, at the same time, to cope with new financial demands. University students usually face new eating habits, and new diseases, as well as new places to live, new mobility routines and new climates. However, some students are unprepared and/or struggle to deal with all these changes that come with this new-found reality. Balancing the new social life with the new academic life, besides all the environment changes, may not be that easy, particularly to international students, since they face unique challenges: the adjustment to a new country and culture, a new education system and, most of the time, to deal with a new language (Coates \& Dickinson, 2012).

There are many studies which findings indicate the correlation between homesickness and adjustment issues in international students. Homesickness is defined as a state of distress experienced by those who have left their homes and find themselves in a new environment, causing related mental and physical health problems (Furnham \& Bochner, 1986; Van Tilburg, Vingerhoets, \& Van Heck, 1996). It is seen as a negative emotional state, related to the separation from home and close persons, as well as to difficulties in adjusting to the new place and it is characterized by obsessive thoughts about home and negative thoughts about the new environment (Fisher, 1989; Stroebe, Schut, \& Nauta, 2015). Accordingly, the levels of homesickness seem to be higher in international students than in home students (Poyrazli \& Lopez, 2007) and also when international students had left their family (wives and children) in their home countries (Lewthwaite, 1996).

Another hindrance experienced by international students that appears as the biggest obstacle to their adjustment are the language barriers (Sawir, Marginson, Forbes-Mewett, Nyland, \& Ramia, 2012; Smith \& Khawaja, 2011). Several studies highlight the difficulties that international students go through regarding communication in the host language, namely English. These difficulties, at an academic level, could be related with understanding the lectures, taking notes, reading academic literature and understanding the informal host language of home students and university's staff (Lewthwaite, 1996; Poyrazli, 2003; Yeh \& Inose, 2003). Therefore, the host language proficiency held by international students plays a crucial role for them to successfully complete their studies in a foreign languagespeaking learning environment (Andrade et al., 2014; Kwon, 2009; Poyrazli \& Grahame, 2007; Poyrazli \& Kavanaugh, 2006). Language proficiency is important not only for academic purposes, but also for the social adjustment of international students (Akanwa, 2015; Andrade, 2006), namely with home students (Peacock \& Harrison, 2009; Sherry, Thomas, \& Chui, 2010) 
and locals (Daroesman, Looi, \& Butler, 2005; O’Reilly, Ryan, \& Hickey, 2010; Sawir et al., 2012).

Social support is another hindrance international students endure. Several studies indicate that social support may arise from various sources, including family, peers (host students and co-nationals), faculty staff or locals and could enhance the well-being of these students (Ward, Bochner, \& Furnham, 2001). Social support is also seen as an important predictor in the psychological adaptation during cross-cultural transitions (Brisset, Safdar, Lewis, \& Sabatier, 2010; Kenyon, Frohard-Dourlent, \& Roth, 2012; Ward \& Rana-Deuba, 2000). Studies' findings indicate that students with higher levels of social support experience lower levels of acculturative stress (Poyrazli, Kavanaugh, Baker, \& Al-Timini, 2004; Yeh \& Inose, 2003) and experience less risk of depressive feelings (Dao, Lee, \& Chang, 2007; Sumer, Poyrazli, \& Grahame, 2008).

Social interactions with home students are another adjusting issue concerning international students (Andrade \& Evans, 2009; Ward et al., 2001). Friendships with home students are considered vital for international students since they allow practicing the host language, learning the host culture and feeling accepted (Andrade et al., 2014; Gu, 2011; Ruble \& Zhang, 2013; Ryan, 2005; Zhou, Jindal-Snape, Topping, \& Todman, 2008). However, some studies indicate that home students are not disposed to make the effort to make friends with international students, particularly if the conversation turns to be difficult (Ryan, 2005) and rather prefer to work and develop friendship with other home students (Peacock \& Harrison, 2009). These conclusions are underlined by the findings of Poyrazli and Grahame (2007) which seem to indicate that international students' social interactions, mainly with U.S. students, are not very frequent. Nevertheless, Trice (2004) findings indicate that the frequency of interaction between international and home students, in this case U.S. students, is extremely variable according to the home country of the international students. Her findings conclude that coming from Western Europe and having good English proficiency has a positive impact in the frequency of social interaction that international students have with U.S. students.

Perceived prejudice and discrimination practice, often related with ethnicity and the students' home countries, affects the adjustment of international students enrolled in host universities, as indicated in some studies (Constantine, Anderson, Berkel, Cadwell, \& Utsey, 2005; Sodowsky \& Plake, 1992), which conclude that international students reported higher levels of discrimination than home students (Poyrazli \& Lopez, 2007). Additionally, research findings stress that international students also experience different forms of discrimination and prejudice outside the university's campus (Poyrazli \& Grahame, 2007), often related to language proficiency barriers (Sawir et al., 2012). 


\section{The international Students From Portuguese-Speaking African Countries}

The Portuguese-Speaking African Countries are former Portuguese colonies: Angola, Cape Verde, Saint Tome and Principe, Mozambique and Guinea-Bissau. This five countries share the inherited language and some cultural traits of a common history from the colonial relation with Portugal together with their sovereign interests today.

Portuguese-Speaking African Countries' HE still has some disadvantaged situation or even does not exist, which contributes to the large number of students deciding to proceed their studies abroad, namely in Portugal (Faria \& Costa, 2012). Since 1975 (terminus of the Portuguese colonization) Portuguese universities host students from these new countries whose number never stopped increasing since then (Faria, 2009; Semedo, 2010).

Most students from Portuguese-Speaking African Countries choose Portugal due to the shared Portuguese language, historical issues and previous connections with Portugal and Portuguese relatives or friends, the prestige of the Portuguese HEI or because of the guarantee that they can enroll in the Portuguese universities due to cooperation agreements (Costa, 2012; Elimbi, 2012; Faria, 2009; Gusmão, 2011; Jardim, 2013; Mourato, 2011; Palma, 2004; Pessoa, 2004). Some students from PortugueseSpeaking African Countries choose Portugal also due to good references from former students from Portuguese-Speaking African Countries in Portugal (Ferro, 2010).

As international students, those from Portuguese-Speaking African Countries experience some hindrances. According to the literature, on one hand they are seen, by home students and universities staff, as 'regular' Portuguese students since they 'share' the same language, the Portuguese (Ferro, 2010), so it is assumed that students from these countries know the Portuguese culture and language (Casa-Nova, 2005). On the other hand, the literature review also reveals that these students' difficulties in their academic and social life in Portugal are mostly shared with other international students. Pereira and Motta (2005) state that students from Portuguese-Speaking African Countries face the first hindrance when they arrive in Portugal since, due to bureaucratic issues related to their visa, they start the school year much later than their peers. This late arrival influences these students' adjustment to the new academic and social environment (Pereira \& Motta, 2005). Some studies also indicate that they experience feelings of nostalgia and homesickness (Pacheco, 1996; Duque, 2012) and also seem to have difficulty in finding accommodation (Figueiredo, 2005; Pacheco, 1996; Pereira \& Motta, 2005; Rocha, 2012).

Although Portuguese is the official language of these students' home countries, most of them rarely use it in their everyday life. On a daily 
basis, they tend to use their mother languages, such as Creoles. And if they use Portuguese, it is a Portuguese variation, different from European Portuguese. In this sense, the major hindrance faced by these international students is the language barrier, as it affects both academic and social life (Brito, 2009; Ferro, 2010; Mourato, 2011; Pacheco, 1996; Pereira \& Motta, 2005; Semedo, 2010).

Among the hindrances experienced by these students, financial issues are also on the top difficulties. Some studies' findings indicate that, most of the time, scholarships are received very late (up to 5-8 months after the student' arrival in Portugal) and that the amount of the scholarships from their home countries is insufficient to cover accommodation costs, food, clothing, educational materials and university fees in Portugal (Duque, 2012; Ferro, 2012; Figueiredo, 2005; Jardim, 2013; Pacheco, 1996; Pereira \& Motta, 2005).

Most of these students experience difficulties regarding the teaching and learning processes. To begin with, the Portuguese education system is very different from what exists in their home countries (Casa-Nova, 2005). These differences originate that they lack some important prior learning, which adds to the difficulty of dealing with the new academic demands (Brito, 2009; Casa-Nova, 2005; Ferro, 2010; Jardim, 2013; Mourato, 2011; Pereira \& Motta; 2005; Santos, Lamares \& Fernandes, 2012). The shortage of important basic knowledge, namely in mathematics, originates feelings of frustration and affects academic performance and achievement, underlining the importance of prior learning in academic performance (McKenzie, Gow, \& Schweitzer, 2004; McKenzie \& Schweitzer, 2001). Likewise, also the Portuguese methods of teaching and learning are very different from those that students from Portuguese-Speaking African Countries are used to (Ferro, 2010). Differences take place not only at the curriculum level and extension but also, for instance, in what concerns the methodologies used, often supported in on-line resources not available in their home countries, or the emphasis in experimental work usually accomplished in cooperative and collaborative team work.

On top of these differences, some studies conclude that these students also have some difficulties to become members of the work groups during classes, as they experience some prejudice and discrimination among peers (Ferro, 2010; Marques, 2010; Mourato, 2011; Pereira \& Motta, 2005).

\section{The Role of Higher Education Institutions in Supporting International Students}

Nowadays, every HEI has an International Office. It is widely recognized that international students are an asset to HEI, namely at academic, social and financial levels. HEI should be able to identify potential problems and solutions regarding international students, since they 
gather or should gather different perspectives (institutional, staff, home students and international students' perspectives) and, in this sense, they should promote joint work of different departments and services in order to provide appropriate support to these students. It is important that international students have institutional support right from the beginning of their stay and that this support meets their diverse academic and social needs to allow them to achieve an easier adjustment to university and to decrease the potential negative situations and feelings (Akanwa, 2015; Sovic, 2008).

However, despite the fact that HEI are ever more sensitive to international students' difficulties, there are still many issues to solve. In the literature there are some studies focusing on the institutional support to international students with findings that reveal that there is still much to be done. The majority of the studies emphasize the students' perspectives defending, for instance, that the main focus of the research regarding international students should not be on the students' ability to adjust but rather on their feelings related to satisfaction with their academic program, academic appointment and their nonacademic social relationships (Perrucci \& Hu, 1995). Moreover, it is argued that HEI should offer specific programs to international students (Akanwa, 2015; Suzuki, 2002), namely to provide a variety of programs of English as a second language for international students, taking into account each students' needs (Akanwa, 2015; Andrade et al., 2014; Li, Chen, \& Duanmu, 2010; Mamiseishvili, 2012; Perrucci \& Hu, 1995; Sawir et al., 2012; Suzuki, 2002). These programs may include on-site English language programs to help students improve their levels of English proficiency prior to their arrival (Andrade, 2011) or a careful screening to determine if English language support is needed. A process should also be implemented that allows HEI to track both the success of these students and to what extent students who need this language support actually do receive it (Andrade et al., 2014).

HEI should also promote the relationships between home and international students, by organizing social gatherings, picnics, and other group activities (Perrucci \& Hu, 1995; Ruble \& Zhang, 2013), since it is understood that this kind of activities increase the interactions between the two groups, benefits both parts (Ruble \& Zhang, 2013) and may strengthen several of the positive predictors of satisfaction (Perrucci \& Hu, 1995). The literature suggestions concerning the HEI's International offices emphasizes its role in the organization of more welcoming sociocultural events at the beginning of the academic years ( $\mathrm{Li}$ et al., 2010) as well as its crucial role keeping international students informed about their new academic life (Akanwa, 2015). HEI are also invited to reinforce the close collaboration between their different structures so that supporting international students becomes a joint responsibility of an extended HEI community, including faculties and academic advisors (Mamiseishvili, 2012). HEI must provide 
workshops, retreats and other activities concerning diversity and multiculturalism (Suzuki, 2002) in order to promote a better understanding of international students' specific needs (Akanwa, 2015).

Regarding the teaching and learning processes, the importance of a Tutor figure is underlined, since it is understood that Tutors' advices may reduce students' stress and improve their confidence to carry on their studies (Li et al., 2010). It is also proposed that HEI, namely their Professors, could incorporate more cooperative learning activities into their classes in order to meet the academic and social needs of international students (Akanwa, 2015; Mamiseishvili, 2012; Rienties, Nanclares, Jindal-Snape, \& Alcott, 2013).

In the case of Portugal and its students coming from PortugueseSpeaking African Countries, the literature seems unanimous denouncing the common sense idea that there are no cultural and social differences between them and their Portuguese colleagues because, allegedly, they know the Portuguese language and culture (Casa-Nova, 2005). As a result, and in accordance with Casa-Nova (2005), there has been some negligence from HEI regarding the socio-cultural specificities of these students. In this sense, there's a need that the universities develop and implement strategies to improve the reception and the integration of the students from the Portuguese-Speaking African Countries. In order to improve their adjustment, some studies mention the importance of actions such as: rethinking the welcome programs (Santos et al., 2012), implementation of tutorial programs (Rocha, 2012; Santos et al., 2012) and improving the social support, namely financial support (Mourato, 2011; Santos et al., 2012).

\section{RESEARCH METHOD}

The study is a part of a broader research project, which main goal is to make recommendations in order to steer institutional change and, therefore, enhance nontraditional students' support system within Portuguese HEI. It focuses on two Portuguese HEI: University of Aveiro (UA) and University of Algarve (UAlg) and comprises the data analysis from the academic year 2013/2014.

\section{Setting}

Located in the southern part of Portugal, the UAlg is a young public university. Founded in 1979, the UAlg arose from the merging of two preexisting institutions - the University of Algarve and the Polytechnic Institute of Faro - which makes it somewhat different from most universities given that faculties and schools of both systems co-exist, a common characteristic with UA. In the academic year of 2015/2016, there are 7,332 
students enrolled in graduate and post-graduate programs (3 Faculties, 4 Polytechnic schools and 1 Department).

According to institutional data, in the academic year of 2013/2014 there were 129 students from the Portuguese-Speaking African Countries attending the UAlg, in Bachelors ( $\mathrm{n}=91$ ) and Masters' degrees ( $\mathrm{n}=38)$. Regarding the nationality of these students, the majority were from Cape Verde ( $\mathrm{n}=78)$, Angola $(\mathrm{n}=21)$, Mozambique $(\mathrm{n}=12)$, Guinea-Bissau ( $\mathrm{n}=$ 12 ) and, lastly, Saint Tome and Principe $(n=6)$. Concerning the masters' degrees with more students from the Portuguese-Speaking African Countries they are Biology, Electronic and Telecommunications Engineering. In relation to degrees, the most chosen by these students are Civil Engineering and Marine Biology.

The UA, located in the center of Portugal, near the Atlantic Ocean, is a public university founded in 1973 . The UA soon became one of the most dynamic and innovative universities in the country with around 15.000 enrolled students in graduate and post-graduate programs, having a unique model of governance (16 Departments, four Polytechnic Schools and various training centers).

The UA has an International Cooperation for Development policy, which supports several cooperation agreements in the Education field between the University and the governments of the five PortugueseSpeaking African Countries. According to the institutional data, in the academic year of 2013/2014 there were 248 students from the PortugueseSpeaking African Countries attending the UA, most of them in Bachelors and Masters' degrees $(n=185)$. Regarding the nationality of these bachelors and masters' students, the majority are from Cape Verde $(n=68)$ and Mozambique $(\mathrm{n}=54)$. There were 36 students from Saint Tome and Principe, 18 students from Angola and only nine from Guinea-Bissau. The three degrees with more students from the Portuguese-Speaking African Countries are Management, Meteorology, Oceanography and Geophysics and Public Administration. Regarding the masters' degree, the three most chosen by these students are Languages, Literatures and Cultures, Accounting and Public Administration and Management. In short, there were 185 students from Portuguese-Speaking African Countries enrolled at UA and other 129 at UAlg, in a total of 314, attending bachelor and master degrees. PhD students, students attending specializations courses and technological specialization courses are not included in this study. From those 314 students, 146 were from Cape Verde, 66 from Mozambique, 42 from Saint Tome and Principe, 39 from Angola and 21 students were from Guinea-Bissau.

A qualitative approach was taken for this study. As Bogdan and Biklen (1991) said, a qualitative research allows researchers to understand different perspectives of the same reality, since qualitative methods give 
primacy to the social actor's subjective experience as a source of knowledge (Almeida \& Freire, 2003). In this sense, we conducted a broad set of semistructured interviews with Portuguese-Speaking African Countries' students, with their Professors and Courses Directors and also with the HEI' staff. These interviews occurred during the first year of the research project, the academic year of 2013/2014.

Data validation was achieved through triangulation, which, in this study, refers to the use of multiple data sources (interviews with Students, Professors, Courses Directors and HEI's Staff). This means examining the consistency of different data sources from within the same method (Denzin, 1998; Patton, 1990) in order to develop a comprehensive understanding of the phenomena (Patton, 1999). According to Denzin (1998) data triangulation allows enriching the findings and therefore provides researchers with a deep and wide understanding of reality (Denzin, 1998; Patton, 1990).

\section{Participants}

In relation to the students interviewed, the study sample consists of 31 students (10\% of the 314 enrolled in both HEI), which were selected by contacts provided by the Social Services or through personal contacts. Regarding students' nationality, 17 were from Cape Verde, four students were from Angola, four were from Mozambique and other four were from Saint Tome and Principe. Two students were from Guinea-Bissau. The sample comprises 19 females and 12 males, aged between 18 and 38 years. 21 students were attending Bachelor degrees and ten were attending Master degrees. Regarding the length of their stay in Portugal, the interval varies from five months to 16 years. The other interviewees were 15 Professors and Course Directors and nine members of different support offices of both Universities (Cooperation Office - Rectory (R), Social Services (SS), Pedagogical Office (PO) and Student Ombudsperson (SO)).

\section{RESULTS}

\section{Main Hindrances Experienced by International Students Coming From Portuguese-Speaking African Countries}

\section{Awkward arrival time due to visa issues}

According to the interviewed students, their main hindrances are related with the transition to Portugal, since they have serious difficulties to obtain their visas due to bureaucratic issues. These visa issues have serious repercussions in academic and social life, since they define when students arrive to the Portuguese Universities. They arrive mostly in the middle of 
the first semester, which affects very negatively their academic and social adjustment.

When I was on my way to Portugal, I had many problems with the visa. When I finally arrived, the first semester had already finished (UA, Female, 20, Cape Verde, BS in Meteorology, Oceanography and Geophysics)

When you arrive in January or February [because of the delay obtaining the visa] you've already lost a whole semester. This means you're left behind. It's complicated. When I fall here, I didn't know anybody and, of course, the professors didn't know me (UA, Female, 22, Cape Verde, BA in Political Science)

The Professors of these international students are aware of this 'visa issue', regretting that the Portuguese Foreign Affairs Ministry as well as the students' home countries do not solve the problem and also regretting the negative impact that it has in the students' academic life.

Most of the students arrive after the beginning of the academic year. That's an old problem that should have been solved many years ago. Someone should press the government so they can, at least, arrive on time. The agreements between the States should foresee this, in order to simplify the visa issues. At this level, the Universities don't have much capacity to negotiate. (UA, Director of BS in Account)

This late arrival also implies that the students from these countries miss the freshmen reception (praxe, in Portuguese), which, as all the social activities developed, intends to promote the freshmen integration in the academia. Thus, international students' relationships with home students are not made easier. However, some Professors stated that the main reason why these students do not socialize with home students is related to financial issues, as they experience serious economic problems and they do not have extra money to spend in going out, dinners, and so on.

They don't integrate faster because they have financial issues. Due to these financial difficulties they can't go out with their colleagues (UA, Director of BA and Master in Languages and Cultures)

\section{Financial problems}

Most of the interviewed students reported these financial problems since they subsist with scholarships from the governments of their home countries, which are normally received with a delay of several months. 
Moreover the amount of the scholarship in most cases is not enough to cover all expenses in the Portuguese reality.

In the beginning, with the delay of the payment of the scholarship [my life] was very complicated. For instance: I arrived in September and I only got the scholarship in November. It was very complicated to pay for the dorm. It was difficult to pay for the photocopies...I didn't have any money. I managed to buy the copies, but I felt terrible. (UAlg, Female, 19, Cape Verde, BS in Orthotics and Prosthetics)

These financial problems are also recognized by both universities' Social Services and by the Professors.

We know that the amount of the scholarships is not enough for them to pay for everything: the University fees, food, clothes, learning materials, etc... (UAlg, Member of the Social Services Staff)

The delay in the scholarships' payment is really a huge problem. That's why here, in the Social Services, we always have our doors opened to help the African students who ask us for help. Right now, we have a few being [financially] helped. (UAlg, Administrator of the Social Services)

They face economic problems. Firstly because normally they come with scholarships and... well, I don't know the exact amount of the scholarships but I think its little money. So what should they do? They try to find a job here, and they work while they're studying. That's why they only obtain very low grades (UAlg, Director of the BS in Marine Biology)

\section{Homesickness}

Another hindrance experienced by the students coming from Portuguese-Speaking African Countries is the feeling of homesickness, as they are far away from home and from their relatives and friends.

In the beginning, it was very hard for me. I came in the 25th September and until the 6th December everything was okay. That day I start crying and I call my parents. I told them I wanted to go back and my father said to me: « - Okay, no problem, I'll send you the ticket and you'll study here». But I said: «- No, I'd rather stay here». I cried for a couple more days. But now it's solved, I learnt. (UAlg, Female, 20, Cape Verde, BS in Pharmacy) 
It was very hard in the beginning, I confess. It was very difficult to stay away from my family, especially from my mother. Then I got used to it. (UAlg, Female, 21, Cape Verde BA in Tourism)

The students from the Portuguese-Speaking African Countries also have to deal with some prejudices and discrimination behaviors, namely when they try to find accommodation.

When the owner came to give us the key and to receive the money - because it was a kind of an emergency - he said: «- But I didn't know you were Africans...». And my friend said «And so, what's the problem? ». «No, because you Africans, you're noisy, you don't know how to get along with other people». He said this and that, he call us pigs and he didn't give us the key. (UAlg, Female, 22, Cape Verde, BS in Dietetics and Nutrition)

\section{Language barriers}

Despite the fact that these students come from countries where Portuguese is the official language, the interviewees stated that they mainly use their mother tongues, such as local creoles. They assumed that European Portuguese is very different from the Portuguese they know. Therefore, the language barrier is one of the main hindrances experienced by these students, since it affects their academic and social life.

In Cape Verde, we only speak Portuguese at school. We speak Portuguese in conferences or when we're in contact with Portuguese people or with other people that speak Portuguese, otherwise, among Africans, we use the Creole. Creole is our mother tongue. The fact that Portuguese is our official language doesn't imply that we stop using our mother tongue. (UAlg, Male, 21, Cape Verde, BA in Culture and Heritage Studies) I'm telling you, in the first year I thought to myself: «Speaking Portuguese is so difficult that feels like having a rope around your neck. Well at least for me it's difficult. (UAlg, Female, 22, Cape Verde, BS in Nutrition Sciences)

I really had problems [with the Portuguese language]! When I arrived, I listened to the people speaking and I didn't understand a thing. It looked as everybody was speaking so fast! But I don't feel it anymore. (UAlg, Female, 23, Guinea-Bissau, BS in Marine Biology)

It must be said that the language barrier has a deep impact in academic success. In the perspective of these students, on one hand, it is very difficult to understand the Professors and, on the other hand, they don't feel comfortable to put questions and to be active in classes. 
We Capeverdians, we do speak Portuguese but, in my case it's difficult to speak it. Sometimes people use vocabulary that I don't know and I feel lost. This, hampers the comprehension of the message the Professor wants to transmit. (UA, Male, 24, Cape Verde, BA in Public Administration)

[The mastery of the Portuguese language] is really a constraint. Sometimes I want to say something, but my language is not in accordance with what you Portuguese people are used to listen or say; sometimes I use expressions that cause astonishment: «what is he trying to say?» Do you understand? It's embarrassing when all the class gets astonished by something we're saying, by an expression we're used to use, something normal for us (UA, Male, 24 Saint Tome and Principe, BA in Public Administration)

According to the Professors, some of these students have a low profile participation in the classroom, they're even considered shy, but their silence is due to the lack of language proficiency, as they feel insecure and sometimes ashamed to speak Portuguese.

In the beginning they are very shy, they don't participate, they don't speak. But how could they participate? Everybody is speaking in Portuguese and they're foreigners. Usually, they don't participate much, they tend to stay in their corner. But it depends on the personality of each one, on the self-confidence (UAlg, Professor of Mathematics in the BS in Pharmacy)

They face problems concerning the language. Despite the fact that they come from Portuguese speaking countries, they have a very elementary knowledge of the language. They write poorly, they have oral comprehension problems. They don't understand well the things we ask them. At the end of the classes, when they come to us with questions, there's where we realize they don't master the language even orally. If they can't express themselves orally, they can't express themselves through writing. Normally they face huge problems writing their Master's thesis (UAlg, Director of the BS in Marine Biology)

\section{Relationship with home students}

The relationships with home students are not always easy. Nevertheless, the interviewees referred that they have very good friends among home students and that they were very supportive.

As soon as they realized I arrived late, everybody came to me saying: «- you're going to need this and that, class notes etc.» And 
thanks to them I managed to integrate in everything. (UA, Male, 27, Saint Tome and Principe, BS in Management)

All my colleagues were asking if I was following the matters; if I was following the lecturer and taking notes. Whenever I couldn't take notes they gave them to me. (UA, Male, 24, Cape Verde, Bachelor in Public Administration)

On the other hand, some students indicate that it was very difficult for them to establish relationships with home students in classes, for instance in group work, or outside the classes.

When I enter the classroom and sit nobody speaks to me. Only if I speak to anyone, he or she speaks to me. Until now. We may even work together, but when they see me on the street they act as if they don't know me (UA, Female, 21, Cape Verde, BS in Meteorology, Oceanography and Geophysics).

We have great difficulties to form work groups with them. I had great difficulties. I wanted to form a group, but the people put me by. (...) There is some kind of prejudice (UAlg, Male, 27, Mozambique, BS in Civil Engineering)

The difficulties experienced by students from Portuguese-Speaking African Countries during classes are also perceived by some Professors and Course directors, namely when students have to work in groups.

It's harder for them [to work in groups]. They tend to form groups among them. Of course there are some nice exceptions of the popular students that easily integrate themselves. But generically, they hardly integrate in home students groups (UAlg, Director of the BS in Dietetics and Nutrition)

\section{Prior learning and teaching and learning methods}

Another hindrance faced by the students from African PortugueseSpeaking Countries is related to the differences between their home country Education System and the Portuguese one. These students feel that their prior learning is not enough to deal with the new demands of the Portuguese Higher Education, which originates feelings of frustration and sadness.

[The educational system] is different. In terms of Algebra, there were some things I didn't know. When I arrived, I realize I really had no bases. At school I didn't learn Computer Science, I knew nothing about Programming (UA, Female, 21 Cape Verde, BS in Meteorology, Oceanography and Geophysics)

Sometimes the professor says: «- I'm not going to talk about this because you've already studied it in the secondary». But there are 
subjects you study here in Portugal that I've never heard about. (UA, Female, 20, Cape Verde, BS in Meteorology, Oceanography and Geophysics)

This 'prior learning problem' is also identified by Course Directors and Professors, as well as by the Head of the Social Services. They were unanimous when indicating that the lack of some basic knowledge negatively affects the academic success of these students.

They have difficulties related directly to their lack of prior preparation, therefore is very hard for them to follow the courses (UAlg, Director of the BS in Marine Biology)

The academic preparation they bring from their countries has nothing to do with our demands. (UAlg, Administrator of the Social Services)

Another issue is the teaching and learning strategies, which in the host country are very different from those at the home country.

Here, subjects are taught in a very fast pace. We were not used to it. (UAlg, Male, 25, Angola, Master in Biology)

When I arrived to the math's class I found it so different. The Professor spoke too fast and passed through the things so fast. Back in those days I almost felt depressed. I was used to do everything in the right time, I never left anything behind. I came with those habits. That's a kind of obligation, so I felt a bit like a fish out of the water. (UAlg, Male, 19, Cape Verde, BS in Civil Engineering)

\section{Support Structures and Actions Offered by the two Universities}

Taking into account the data collected through the interviews with some members of the universities' staff, it became clear that the delay in the payment of scholarships originates serious difficulties regarding food and accommodation, among other aspects of these students' life.

According to the institutional interviewees, the main support structures of both HEI are the Social Services. The support given by these offices comprises accommodation, social scholarship, food support and social merit scholarship. It is important to refer that Social Services are the 'face' of institutional support in what Portuguese-Speaking African Countries' students are concerned. It is also this office that boost sports activities within campus.

In relation to the support given by the Student Ombudsperson, its main role, regarding these particular students, is to connect them with the different structures of the universities taking into account each one's needs. It works in the perspective that there is a partnership and cohesive 
connection with all the structures of the university, which allows integrated responses to the problems, namely those of the students from PortugueseSpeaking African Countries.

Another support structure is the Pedagogical Office (PO). It provides support to students in matters related to general aspects of their academic and personal lives, while respecting confidentiality. Regarding students from the Portuguese-Speaking African Countries, most of them come to this office with scholarship's problems and from there they are sent to the Social Services. Some students can, for instance, appeal to the PO looking for academic support since the Educational System in their home country is very different from the Portuguese one; in these cases, the PO provides academic support through its network of volunteers.

Considering the Rectory's perspective, it is important to analyze and to improve the welcoming and the integration of these students, underlining that it's important that they know where and with whom they can solve their problems. Moreover, both HEI have strong Students Associations, which have specific structures dedicated to the students from the Portuguese-Speaking African Countries and that are managed by them.

Additionally, in order to better support these students, the different structures of both HEI also articulate with several national and local institutions, such as: (a) The Serviço de Estrangeiros e Fronteiras - SEF (Portuguese acronym to Emigration Services), a security service organized vertically under the Ministry of Home Affairs; (b) the Health Center; (c) the Municipalities of Aveiro and Faro - the cities where the universities are located. It is also important to refer that in both HEI their International Offices have no relation with students from the Portuguese-Speaking African Countries as they are dedicated to other mobility programs such as ERASMUS (European Mobility Program) and to Brazilian students.

\section{Interviewee's Suggestions to Improve Institutional Supporting Services}

The suggestions made by students from the Portuguese-Speaking African Countries and their Professors are related to different aspects of the academic and social life of these students.

\section{a) Institutional support}

Some Professors stressed the need to improve the dissemination of the existing institutional support structures among the Academia in general and the Professors in particular, as they argue that when more informed they could better support students from the Portuguese-Speaking African Countries.

I think the teaching staff doesn't really know all the efforts made by the University to support this students, namely at the Social Services level. I know we could spread it more... The students are 
immediately taken to the Social Services, so they know what their benefits from the Social Services are. But the teaching staff stays at out of this process. (UA, Director of BA in Language and Cultures).

We don't have the slightest idea of the support that is being given to these students. But we should know, don't we? I may have colleagues for whom the least they know, the better. But I think it's the kind of information that could help us to deal with them. (UA, Director of Master in Public Administration)

Similarly, the students from the Portuguese-Speaking African Countries refer the need of a better dissemination of the institutional support available among the other students. They suggest that at the moment of the enrollment the Academic Services could provide more information regarding the institutional support.

In relation to the delay with which students coming from the Portuguese-Speaking African Countries arrive at the beginning of the academic year, it is suggested that the host institutions organize a specific welcome program, providing all important information and to make them feel welcome and informed.

In the beginning of the academic year we should have a welcome ceremony for the students coming from abroad, - because there are always lots of students from abroad with a brief explanation about the University of the Algarve and about the region. This and other information that may be important to them. (UAlg, Female, 21, Cape Verde, BA in Tourism)

\section{b) Financial problems}

Since financial problems are a serious hindrance experienced by Portuguese-Speaking African Countries' students, which have impact in their academic life, as well as in their subsistence in Portugal, there were some suggestions to improve these students' life regarding this issue, namely: to increase the number of accommodations provided by the HEI and design a new support system to help those who lose their scholarship.

The University - maybe in cooperation with the Portuguese government and the government of Cape Verde - should help, reducing the academic fees for African students. When we compare the standards of living of Cape Verde and Portugal... it's difficult for us to pay the fees and live with what remains from the scholarship. There are people that come, spend a year and go back because they can't manage to survive. The families in Cape Verde don't have the conditions to help their children here. (UAlg, Female, 18, Cape Verde, BS in Biomedical Sciences) 
The system of attribution and renovation of the scholarships [should change]. We, African students, we are a kind of immigrants. When we don't have money to pay for the academic fees we must work. We don't have relatives here. We can count only on ourselves. There are students who lost their scholarships and had to stop studying. All those aspects of the attribution of the scholarships should be revised. (UAlg, Male, 38, Mozambique, BA in Corporate Secretaryship).

\section{c) Teaching and learning process}

Regarding the teaching and learning process, the implementation of a Tutorship program was referred by some students and by some Professors. It is understood that this Tutor could support students both academically and socially, which means that since the moment students coming from Portuguese-Speaking African Countries arrive in the Portuguese HEI, there is someone who could help and guide them in every matter, since the process of enrollment and accommodation, to the academic difficulties that these students may experience.

It shouldn't be difficult to give all of them [to the students from Portuguese-Speaking African Countries] the phone number of someone they should contact in case of necessity, to find a room, for instance... This is to say to found someone [among the teaching staff] to be responsible for two or three persons, to go get them at the airport etc. I think this would improve their sense of comfort and safety. This is very important. And this person or another one should keep up with these students during their graduation. A kind of personalized support (UAlg, Director of the BA in Heritage and Cultural Studies)

Another suggestion regarding the teaching and learning processes underlines the lack of prior knowledge, in particular subjects such as mathematics, for instance. It was suggested that those who do not have the needed prior knowledge could have the possibility to attend intensive courses, prior to the main course or during all the semester.

People that feel they don't have enough preparation for one particular course, they should have the possibility to attend propaedeutic classes were they could learn the basic concepts. There are lots of people who don't have the basic preparation to University courses. (UA, Male, 24, Saint Tome and Principe, BS in Management) 
Since most of the students coming from Portuguese-Speaking African Countries experienced learning difficulties for several reasons some Professors suggested the implementation of "zero year" as a preparation year, before the freshmen year. According to these Professors this 'zero year' would be a year of adjustment and pedagogical preparation. In this 'zero year' students could improve their knowledge in particular subjects as mathematics or physics.

[With this 'year zero' system], if they have difficulties in Mathematics or Physics they can attend those preparation classes. Or to refresh some subjects that are absolutely fundamental to the courses (UAlg, Engineering Professor)

\section{d) Language barriers}

Language barriers are one of the major hindrances that students from the Portuguese-Speaking African Countries experience. Students and their Professors are well aware that it is essential to implement some strategies in order to decrease the negative impact that the lack of European Portuguese proficiency has in students' academic and social life. It was suggested that HEI could provide, for instance, additional European Portuguese language training, preceded by a diagnostic test to identify what are the specific difficulties students have.

The University should offer complementary training in Portuguese. Even short duration courses proceeded by a diagnostic assessment. Most of my colleagues agree that this would be of great value, not only for the African students, but for all. (UAlg, Professor in the BS in Dietetics and Nutrition)

Some Professors also suggested that in the first semester of the first year, Portuguese-Speaking African Countries' students should have an intensive six months course of immersion in the language.

In my opinion they need an intensive immersion in Portuguese, in the first year, even before they enter in the University. Lots of reading, writing and text interpretation. This should be something natural for them: to spend a semester reading good texts in Portuguese, discussing them with the Professor, writing essays... one semester that would help them a lot. Even at the Master's level they need the same thing, but it would be harder for them to accept spending a whole semester just studying Portuguese (UA, Director of Master in Public administration) 
Students from Portuguese-Speaking African Countries also defended the implementation of intensive courses not only in Portuguese, but also in chemistry, informatics and English in order to cope with their difficulties.

The University should offer computer science, chemistry etc. They could use voluntary Professors to explain the harder subjects and also Portuguese (UAlg, Female, 22, Cape Verde, BS in Dietetics and Nutrition)

The institution should look after us in order to understand that most of us have problems with English. English private courses are very expensive. [The University should promote] English courses for students with economic difficulties at a price we could pay. That would help us a lot. (UAlg, Male, 25, Angola, Master in Biology)

\section{DISCUSSION AND CONCLUSIONS}

Taking into account the hindrances stated by international students coming from Portuguese-Speaking African Countries in this study, it is possible to argue that they seem to be very similar to the hindrances experienced by other international students, with different home countries, or even experienced by other Portuguese-Speaking African Countries' students in former Portuguese studies. Our findings indicate that these students experience homesickness as other international students (e.g., Furnham, 1997; Poyrazli \& Lopez, 2007). Similarly to the findings from $\mathrm{Li}$ et al. (2010) and some Portuguese studies (e.g., Brito, 2009; Ferro, 2010; Mourato, 2011) regarding the implications of lower proficiency in host language, our results indicate that the low proficiency in European Portuguese seems to contribute to lower levels of academic and social success. Our findings are also consistent with the studies that indicate prejudice and discrimination as a hindrance experienced by international students (Poyrazli \& Grahame, 2007) namely outside the university's campus (Sawir et al., 2012). The difficulty to establish relationships with home students is another hindrance identified in our study that was also mentioned in previous studies (Andrade \& Evans, 2009; Peacock \& Harrison, 2009; Poyrazli \& Grahame, 2007; Ryan, 2005; Ward et al., 2001). Our findings emphasize the importance of prior learning (McKenzie et al., 2004; McKenzie \& Schweitzer, 2001) in the academic success of these students. Due to the fact that the Portuguese Education System is very different from those Portuguese-Speaking African Countries' students have in their home countries, it is clear in our results that the majority lack some needed knowledge to their new academic demands, as mentioned in other studies (Brito, 2009; Jardim, 2013; Mourato, 2011). Our findings also 
indicate that international students from Portuguese-Speaking African countries have serious financial problems with implications in their personal, social and academic life (Duque, 2012; Ferro, 2012; Jardim, 2013). Another hindrance experienced by students from PortugueseSpeaking African Countries that emerged in our findings is related to the transition to Portugal, namely the difficulties to obtain their visa due to bureaucratic issues in their home countries. These results are consistent with the findings of Pereira and Motta (2005).

Despite the support services provided by the two HEI appear to be well-structured and organized, it is clear that they are not enough to cope with these students' needs. The suggestions given by the students themselves and their Professors in order to improve institutional support reinforce the findings of former studies, such as the increase of the host language support (Akanwa, 2015; Andrade et al., 2014; Li et al., 2010; Mamiseishvili, 2012; Perrucci \& Hu, 1995; Sawir et al., 2012; Suzuki, 2002); to implement welcoming programs to the students from PortugueseSpeaking African Countries (Santos et al., 2012); to put into service tutoring projects (Rocha, 2012; Santos et al., 2012) and to review the policies of social support to students, namely financial support (Mourato, 2011; Santos et al., 2012). Other suggestions that emerged in our study are related to the implementation of intensive courses according to the students' needs and the dissemination of the institutional support among students and their Professors, underlining the importance of an 'active institutional voice'.

In his study Akanwa (2015) states that international students "seem to be left on their own upon enrollment as they have to navigate the complex and challenging educational and cultural landscapes of their host universities with little or limited support services” (pp. 280-281). Some recommendations based on this study are:

\section{Support in European Portuguese Language}

Once and for all, Portuguese HEI have to understand that the majority of these students do not have proficiency in European Portuguese. HEI should offer to these students the opportunity to improve their Portuguese skills by providing intensive courses, with free-access, in class and online. Just as HEI provide Academic English Courses, they should also provide Academic Portuguese Courses. Besides the course, it is also important to obtain a true measure of students' language skills, before and after the intensive course.

\section{Support in the acquisition of missing prior knowledge}

It is important that the students coming from Portuguese-Speaking African Countries can have the same opportunities to achieve academic success as their Portuguese peers. Providing intensive courses, namely on 
mathematics or chemistry, could help these students to stay up to date with these and other particular subjects.

\section{Support in social interactions on campus}

The implementation of a dedicated welcoming program is very important, since these students arrive very late in the academic year and miss all the reception activities dedicated to the freshmen.

\section{Better dissemination of the institutional support provided among HEI staff and students}

HEI should provide all necessary dissemination procedures to better inform the Professors and other HEI staff about the support that students may benefit in order to make them a mean of dissemination of the provided students support. At the same time, it is imperative that students from Portuguese-Speaking African Countries are informed by institutional channels, since the moment of their enrollment at the academic services.

\section{Acknowledgments}

This paper was financed by National Funds provided by Foundation for Science and Technology (FCT) through project PTDC/IVC-PEC/4886/2012 and project UID/SOC/04020/2013.

\section{REFERENCES}

Akanwa, E. (2015). International students in Western developed countries: History, challenges, and prospects. Journal of International Students, 5(3), 271-284.

Almeida, L., \& Freire, T. (2003). Metodologia da Investigação em Psicologia e Educação. $3^{a}$ edição. Braga: Psiquilíbrios Edições.

Andrade, M. S. (2006). International students in English-speaking universities: Adjustment factors. Journal of Research in International Education, 5(2), 131-154.

Andrade, M. S. (2011). Extending support for English language learners: A university outreach program. International Journal of Multicultural Education, 13(2), 1-18.

Andrade, M. S., \& Evans, N. W. (2009). International students: Strengthening a critical resource. Lanham: Rowman \& Littlefield Education.

Andrade, M. S., Evans, N. W., \& Hartshorn, K. J. (2014). Linguistic support for non-native English speakers: Higher education practices in the United States. Journal of Student Affairs Research and Practice, 51(2), 207-221.

Bogdan, R., \& Biklen, S. (1991). Investigação Qualitativa em Educação. Uma Introdução à Teoria e aos Métodos. Porto: Porto Editora.

Brito, V. (2009). Vivências Adaptativas e desempenho académico dos estudantes CaboVerdianos da Universidade de Coimbra. Dissertação de Mestrado em Ciências da Educação, área de especialização em Pedagogia universitária. Coimbra: Faculdade de Psicologia e Ciências da Educação.

Brisset, C., Safdar, S., Lewis, J. R., \& Sabatier, C. (2010). Psychological and sociocultural adaptation of university students in France: The case of Vietnamese international students. International Journal of Intercultural Relations, 34(4), 413-426.

Casa-Nova, M. (2005). (I)migrantes, diversidades e desigualdades no sistema educativo português: balanço e perspetivas. Ensaio: Avaliação e Políticas Públicas em Educação, 13(47), 181-216. 
Coates, N., \& Dickinson, J. (2012). Meeting international postgraduate student needs: a programme-based model for learning and teaching support. Innovations in Education and Teaching International, 49(3), 295-308.

Constantine, M. G., Anderson, G. M., Berkel, L. A., Cadwell, L. D., \& Utsey, S. O. (2005). Examining the cultural Counseling, adjustment experiences of African international college students: A qualitative analysis. Journal of Counseling Psychology, 52(1), 5766.

Costa, A. B. (2012). Formação de Quadros Superiores Moçambicanos em Portugal: Trajetórias, Identidades e Redes Sociais. Cadernos de Estudos Africanos, 23, 131-158.

Dao, T. K., Lee, D., \& Chang, H. L. (2007). Acculturation level, perceived English fluency, perceived social support level, and depression among Taiwanese international students. College Student Journal, 41(2), 287-295.

Daroesman, S., Looi, K., \& Butler, D. (2005). Survey of final year international students on their experience of the University of Melbourne. University Planning Office, University of Melbourne.

Denzin, N. K. (1998). The Art of Interpretation, Evaluation, and Presentation. In Norman K. Denzin \& Yvonna S. Lincoln (eds.), Collecting and Interpreting Qualitative Materials (pp. 313-344). Thousand Oaks: Sage Publications.

Duque, E. (2012). Representações e Expetativas dos estudantes universitários dos PALOP. In VII Congresso Português de Sociologia, Universidade do Porto - Faculdade de Letras Faculdade de Psicologia e Ciências da Educação, 19 a 22 junho 2012.

Elimbi, Y. (2012). Les parcours des étudiants étrangers africains en France. Paris: Université Paris 1 Panthéon-Sorbonne.

Faria, M. \& Costa, A. B. (2012). Introdução. In Ana Bénard da Costa e Margarida Lima de Faria (Orgs.), Formação Superior e Desenvolvimento - Estudantes Universitários Africanos em Portugal (pp.5 - 16). Coimbra: Edições Almedina.

Faria, M. (2009). Cooperação no âmbito do ensino superior: ser estudante angolano em universidades portuguesas. Pro-Posições, 20(58), 45-63.

Ferro, M. (2010). Teoria crítica e aconselhamento: para uma intervenção multicultural com os estudantes da cooperação na Universidade de Coimbra. Tese de Doutoramento em Psicologia. Coimbra: Universidade de Coimbra.

Figueiredo, M. (2005). Estudantes dos PALOP na Universidade de Évora: do Levantamento das Dificuldades e Necessidades à Procura de Soluções. Dissertação de Mestrado em Sociologia. Évora: Universidade de Évora, Departamento de Sociologia.

Fisher, S. (1989). Homesickness, cognition and health. Hove, UK: Lawrence Erlbaum.

Furnham, A. (1997). Culture shock, homesickness and adaptation to a foreign culture. In M. van Tilburg \& A. Vingerhoets (Eds.), Psychological Aspects of Geographical Moves: Homesickness and Acculturation Stress (pp.17-34). Tilburg: Tilburg University Press.

Furnham, A., \& Bochner, S. (1986). Culture shock: Psychological reactions to unfamiliar environments. London: Methuen.

$\mathrm{Gu}, \mathrm{Q}$. (2011). Managing change and transition: Chinese students' experiences in British higher education. In J. Ryan (Ed.), China's higher education reform and internationalisation (pp. 134-150). London: Routledge.

Gusmão, N. (2011). “Na Terra do Outro”: presença e invisibilidade de estudantes africanos no Brasil, hoje. Dimensões, 26, 191-204.

Jardim, B. (2013). Estudantes PALOP no Ensino Superior Português - das Necessidades Sentidas aos Apoios Prestados. Dissertação de Mestrado em Política Social. Lisboa: Universidade Técnica de Lisboa - Instituto Superior de Ciências Sociais e Políticas.

Kenyon, K., Frohard-Dourlent, H., \& Roth, W. (2012). Falling between the cracks: Higher, Ambiguities of international student status in Canada. Canadian Journal of Education, 42(1), 1-24. 
Kwon, Y. (2009). Factors affecting international students' transition to higher education institutions in the United States: From the perspective of the office of international students. College Student Journal, 43(4), 1020-1037.

Lewthwaite, M. (1996). A study of international students' perspectives on cross-cultural adaptation. International Journal for the Advancement of Counselling, 19(2), 167-185.

Li, G., Chen, W., \& Duanmu, J.-L. (2010). Determinants of International Students’ Academic Performance. A comparison between Chinese and other International Students. Journal of Studies in International Education, 14(4), 389-405.

Mamiseishvili, K. (2012). International student persistence in U.S. postsecondary institutions. Higher Education, 64(1), 1-17.

Marques, J. F. (2010). Racismo e Ciências Sociais; um balanço da última década. Travessias - Revista de Ciências Sociais e Humanas em Língua Portuguesa, 10, 151-168.

McKenzie, K., Gow, K., \& Schweitzer, R. (2004). Exploring first year academic achievement through structural equation modelling. Higher Education Research \& Development, 23(1), 95-112.

McKenzie, K., \& Schweitzer, R. (2001). Who Succeeds at University? Factors predicting academic performance in first year Australian university students. Higher Education Research \& Development, 20(1), 21-33.

Mourato, I. (2011). A Política de Cooperação Portuguesa com os PALOP: contributos do Ensino Superior Politécnico. Dissertação de Mestrado em Ciência Política, Cidadania e Governação. Lisboa: Universidade Lusófona de Humanidades e Tecnologias.

O’Reilly, A., Ryan, D., \& Hickey, T. (2010). The psychological and sociocultural adaption of short-term international students in Ireland. Journal of College Student Development, 51, 584-598.

OECD. (2008). Education at a Glance 2007: OECD Indicators. Paris: OECD.

Pacheco, N. (1996). Tempos de "Sozinhez" em Pasárgada: Estratégias identitárias de estudantes dos PALOP em Portugal. Tese de Doutoramento em Ciências da Educação. Porto: Universidade do Porto - Faculdade de Psicologia e Ciências da Educação.

Palma, E. C. (2004). Diplomacia, projecção cultural e APD. Observatório de Relações Exteriores da Universidade Autónoma de Lisboa: Janusonline.

Pascarella, E., \& Terenzini, P. (2005). How College Affects Students: A Third Decade of Research. San Francisco: Jossey-Bass.

Patton, M. Q. (1990). Qualitative Evaluation and Research Methods. Newbury Park: Sage Publications.

Peacock, N., \& Harrison, N. (2009). "It's so much easier to go with what's easy": "mindfulness" and the discourse between home and international students in the United Kingdom. Journal of Studies in International Education (13)4, 487-508.

Pereira, A. \& Motta, E. (2005). Acção Social e Aconselhamento Psicológico no Ensino Superior: Investigação e Intervenção - Actas do Congresso Nacional. Coimbra: SASUC Edições.

Pessoa, I. (2004). Estudantes do espaço lusófono nas universidades portuguesas. Observatório de Relações Exteriores da Universidade Autónoma de Lisboa: Janusonline.

Perrucci, R., \& Hu, H. (1995). Satisfaction with social and educational experiences among international graduate students. Research in Higher Education, 36(4), 491-508.

Poyrazli, S. (2003). Ethnic identity and psychosocial adjustment among international students. Psychological Reports, 92(2), 512-514.

Poyrazli, S., \& Grahame, K. M. (2007). Barriers to adjustment: Needs of international students within a semi-urban campus community. Journal of Instructional Psychology, 34(1), 28-36.

Poyrazli, S., \& Kavanaugh, P. R. (2006). Marital status, ethnicity, academic achievement, and adjustment strains: Students. The case of graduate international. College Student Journal, 40(4), 767-781. 
Poyrazli, S., Kavanaugh, P. R., Baker, A., \& Al-Timini, N. (2004). Social support and demographic correlates of acculturative stress in international students. Journal of College Counseling, 7(1), 73-83.

Poyrazli, S., \& Lopez, M. D. (2007). An exploratory study of perceived discrimination and homesickness: A comparison of international students and American students. The Journal of Psychology, 141(3), 263-279.

Rienties, B., Beausaert, S., Grohnert, T., Niemantsverdriet, S., \& Kommers, P. (2012). Understanding academic performance of international students: The role of ethnicity, academic and social integration. Higher Education, 63(6), 685-700.

Rienties, B., Nanclares, N., Jindal-Snape, D., \& Alcott, P. (2013). The role of cultural backgrounds and team divisions in developing social learning relations in the classroom. Journal of Studies in International Education, 17(4), 332-353.

Rocha, E. (2012). Avaliação dos processos de integração dos estudantes provenientes dos Países Africanos de Língua Oficial Portuguesa no ISCTE. Dissertação de Mestrado em Ciências da Educação. Lisboa: Universidade de Lisboa - Instituto de Educação.

Ruble, R., \& Zhang, Y. B. (2013). Stereotypes of Chinese international students held by Americans. International Journal of Intercultural Relations, 37(2), 202-211.

Ryan, J. (2005). The student experience. In J. Carroll \& J. Ryan (Eds.), Teaching international students: Improving learning for all (pp. 147-151). London: Routledge.

Santos, A., Lamares, I., \& Fernandes, C. (2012). Percurso e vivência académica dos alunos dos PALOP. In Diana Vieira (Eds.). Apoio psicológico no Ensino Superior: Um olhar sobre o futuro. II Congresso Nacional RESAPES-AP (pp. 71-80). Porto: Instituto Superior de Contabilidade e de Administração do Porto.

Sawir, E., Marginson, S., Forbes-Mewett, H., Nyland, C., \& Ramia, G. (2012). International Student Security and English Language Proficiency. Journal of Studies in International Education, 16(5), 434-454.

Semedo, M. (2010). Emoções mistas: integração social e académica dos alunos provenientes dos PALOP. Lisboa: Faculdade de Psicologia, Universidade Lusófona de Humanidades e Tecnologias.

Sherry, M., Thomas, P., \& Chui, W. H. (2010). International students: A vulnerable student population. Higher Education, 60(1), 33-46.

Smith, R. A., \& Khawaja, N. G. (2011). A review of the acculturation experiences of international students. International Journal of Intercultural Relations, 35(6), 699-713.

Sodowsky, G. R., \& Plake, B. S. (1992). A study of acculturation differences among international people and suggestions for sensitivity to within group differences. Journal of Counseling \& Development, 71(1), 53-59.

Sovic, S. (2008). Coping with stress: the perspective of international students. Art, Design \& Communication in Higher Education, 6(3), 145-158.

Stroebe, M., Schut, H., \& Nauta, M. (2015). Homesickness: A systematic review of the scientific literature. Review of General Psychology, 19(2), 157-171.

Sumer, S., Poyrazli, S., \& Grahame, K. (2008). Predictors of depression and anxiety among international students. Journal of Counseling and Development, 86, 429 - 437.

Suzuki, B. H. (2002). Revisiting the Model Minority Stereotype: Implications for Student Affairs Practice and Higher Education. New Directions for Student Services, 97, 21-32.

Trice, A. G. (2004). Mixing it up: International graduate students' social interactions with American students. Journal of College Student Development, 45(6), 671-687.

UNESCO Institute for Statistics. (2009). Global Education Digest 2009: Comparing Education Statistics Across the World. Montreal: UIS.

Van Tilburg, M. A. L., Vingerhoets, A., \& Van Heck, G. (1996). Homesickness: A review of the literature. Psycological Medicine, 26, 899-912.

Ward, C., Bochner, S., \& Furnham, A. (2001). The psychology of culture shock (2nd edition). London: Routledge. 
Ward, C., \& Rana-Deuba, A. (2000). Home and host culture influences on sojourner adjustment. International Journal of Intercultural Relations, 24(3), 291-306.

Yeh, C. J., \& Inose, M. (2003). International students' reported English fluency, social support satisfaction, and social connectedness as predictors of acculturative stress. Counselling Psychology Quarterly, 16(1), 15-28.

Zhou, Y., Jindal-Snape, D., Topping, K., \& Todman, J. (2008). Theoretical models of culture shock and adaptation in international students in higher education. Studies in Higher Education, 33(1), 63-75.

SUSANA AMBRÓSIO, is a PhD student in Education at the University of Aveiro (Portugal). Currently she is a researcher at the Research Center "Didactics and Technology in Education of Trainers" (CIDTFF) at the University of Aveiro. Her PhD research, which is in the last year, focuses on the non-traditional adult students at the University of Aveiro and how their plurilingual repertoires are constructed in a lifelong learning perspective. Her main research interests are Adult Education, Lifelong Language Learning and Plurilingual Repertoires. Email: sambrosio@ua.pt

JOÃO FILIPE MARQUES holds a PhD in Sociology by the École des Hautes Études en Sciences Sociales of Paris. He is Assistant Professor at the Faculty of Economics of the University of Algarve, Director of the Sociology Master Program and researcher of the Centre for Spatial and Organizational Dynamics (CIEO - UAlg). Email: jfmarq@ualg.pt

LUCÍLIA SANTOS, PhD, is a Professor of Physics. Associate Professor Tenure integrates the Department of Physics of the University of Aveiro. She has taught courses and supervised dissertations/theses in Science and Engineering, Health and Teacher Training Courses at the level of Bachelor, Masters and $\mathrm{PhD}$. Main interests in research are: teaching and learning in Physics and non-traditional students in Higher Education. Email: lucilia.santos@ua.pt

CATARINA DOUTOR, is a PhD student in Education at the Institute of Education of the University of Lisbon (Portugal). Her research interest includes the non-traditional students in Higher Education, namely the transition of Portuguese-Speaking African Countries' students to Higher Education, their experiential learning challenges and identity process. Email: catarinadoutor@gmail.com

Manuscript submitted: February 10, 2016

Manuscript revised: April 18, 2016 Accepted for publication: December 31, 2016 